\title{
Howell-Jolly Body Measurement
}

National Cancer Institute

\section{Source}

National Cancer Institute. Howell-Jolly Body Measurement. NCI Thesaurus. Code C74704.

The determination of the number of Howell-Jolly bodies present in a sample. 